Supporting Information

\title{
Fine Control over the Compositional Structure of Trimetallic Core-Shell Nanocrystals for Enhanced Electrocatalysis
}

\author{
Young Wook Lee ${ }^{\dagger, \dagger}$, Hochan Ahn', Seung Eun Lee ${ }^{\dagger}$, Hyunje Woo ${ }^{\dagger}$, and Sang Woo Han* \\ Center for Nanotectonics, Department of Chemistry and KI for the NanoCentury, \\ KAIST, Daejeon 34141, Korea \\ *Corresponding author. \\ E-mail address: sangwoohan@kaist.ac.kr (S. W. Han) \\ These authors contributed equally to this work. \\ ¥Present address: Energy \& Environment Division, Korea Institute of Ceramic Engineering \\ and Technology (KICET), Jinju 52851, Korea
}

\section{Contents:}

1. Supplementary data: Tables S1 and S2

2. Supplemental experiment results: Figures S1-S11 
Table S1. Average sizes, average shell thicknesses, and $\mathrm{Au} / \mathrm{Pd} / \mathrm{Pt}$ atomic ratios of trimetallic core-shell NCs.

\begin{tabular}{|c|c|c|c|c|}
\hline NCs & $\begin{array}{c}\text { Average size } \\
\text { (nm) }\end{array}$ & $\begin{array}{l}\text { Average shell } \\
\text { thickness (nm) }\end{array}$ & $\begin{array}{c}\mathrm{Au} / \mathrm{Pd} / \mathrm{Pt} \\
\text { atomic ratio }\end{array}$ & $\begin{array}{c}\mathrm{Au} / \mathrm{Pd} / \mathrm{Pt} \\
\text { atomic ratio } \\
\text { (after } \mathrm{ADT})\end{array}$ \\
\hline $\mathrm{Au} @ \mathrm{PdPt}$ & $93.1 \pm 9.08$ & $10.1 \pm 1.39$ & 76.7:12.3:11.0 & 79.6:12.3:8.1 \\
\hline $\mathrm{Au} @ \mathrm{Pd} @ \mathrm{Pt}$ & $79.7 \pm 4.20$ & $\begin{array}{c}2.39 \pm 0.22(\mathrm{Pd}) \\
4.91 \pm 0.46(\mathrm{Pt})\end{array}$ & 77.5:12.6:9.9 & 78.7:12.3:9.0 \\
\hline AuPd@Pt & $49.2 \pm 3.11$ & $4.35 \pm 0.26$ & 79.4:13.0:7.6 & $79.4: 13.0: 7.6$ \\
\hline AuPdPt@Pt & $50.3 \pm 7.39$ & - & $78.0: 12.7: 9.3$ & 78.4:12.7:8.9 \\
\hline
\end{tabular}


Table S2. MOR activities and electrolyte conditions of various catalysts.

\begin{tabular}{|c|c|c|c|c|c|}
\hline Catalyst & $\begin{array}{l}\text { Electrolyte } \\
\text { condition }\end{array}$ & $\begin{array}{c}\text { Mass } \\
\text { activity } \\
\left(\mathbf{m A} \mathbf{m g}_{\mathbf{p t}}{ }^{-1}\right)\end{array}$ & $\begin{array}{c}\text { Peak potential } \\
\text { (V vs. Ag/AgCl) }\end{array}$ & $\begin{array}{c}\text { Scan rate } \\
\left(\mathrm{mV} \mathrm{s}^{-1}\right)\end{array}$ & Ref. \\
\hline $\mathbf{A u} @ \mathbf{P d} @ P t$ & $\begin{array}{c}0.5 \mathrm{M} \mathrm{KOH} \\
+0.5 \mathrm{M} \text { methanol }\end{array}$ & 26197 & -0.13 & 50 & This work \\
\hline $\mathbf{A u} @ \mathbf{P d} @ \mathbf{P t}$ & $\begin{array}{c}0.5 \mathrm{M} \mathrm{KOH} \\
+1.0 \mathrm{M} \text { methanol }\end{array}$ & 43184 & -0.03 & 50 & This work \\
\hline $\mathbf{A u} @ \mathbf{P d} @ P t$ & $\begin{array}{c}0.5 \mathrm{M} \mathrm{KOH} \\
+2.0 \mathrm{M} \text { methanol }\end{array}$ & 54864 & 0.08 & 50 & This work \\
\hline Au@Pd@Pt & $\begin{aligned} & 1.0 \mathrm{M} \mathrm{KOH} \\
+ & 1.0 \mathrm{M} \text { methanol }\end{aligned}$ & 43431 & -0.11 & 50 & This work \\
\hline $\mathrm{Pt}$ NCs/rGO & $\begin{array}{c}0.5 \mathrm{M} \mathrm{KOH} \\
+0.5 \mathrm{M} \text { methanol }\end{array}$ & 550 & -0.2 & 50 & 49 \\
\hline PdPt nanowire & $\begin{array}{c}1 \mathrm{M} \mathrm{KOH} \\
+1 \mathrm{M} \text { methanol }\end{array}$ & 3455 & -0.031 & 50 & 50 \\
\hline PdPt nanosponge & $\begin{array}{c}1 \mathrm{M} \mathrm{KOH} \\
+1 \mathrm{M} \text { methanol }\end{array}$ & 5200 & -0.108 & 50 & 51 \\
\hline PdPt NCs & $\begin{array}{c}1 \mathrm{M} \mathrm{KOH} \\
+1 \mathrm{M} \text { methanol }\end{array}$ & 1280 & -0.245 & 50 & 52 \\
\hline $\begin{array}{c}\text { Flower-like PdPt } \\
\text { NCs }\end{array}$ & $\begin{array}{c}0.5 \mathrm{M} \mathrm{KOH} \\
+0.5 \mathrm{M} \text { methanol }\end{array}$ & 9651 & -0.178 & 50 & 53 \\
\hline $\mathrm{PtAuRu} / \mathrm{rGO}$ & $\begin{array}{c}1 \mathrm{M} \mathrm{KOH} \\
+1 \mathrm{M} \text { methanol }\end{array}$ & 3592 & -0.15 & 50 & 54 \\
\hline $\begin{array}{c}\text { PdPt } \\
\text { nanoflower/rGO }\end{array}$ & $\begin{array}{c}1 \mathrm{M} \mathrm{KOH} \\
+1 \mathrm{M} \text { methanol }\end{array}$ & 9230 & -0.02 & 50 & 55 \\
\hline $\mathrm{Pt} / \mathrm{NiO}$ & $\begin{array}{c}1 \mathrm{M} \mathrm{KOH} \\
+1 \mathrm{M} \text { methanol }\end{array}$ & 927 & -0.07 & 50 & 56 \\
\hline Ni@Pt NCs & $\begin{array}{c}1 \mathrm{M} \mathrm{KOH} \mathrm{+} \\
1 \mathrm{M} \text { methanol }\end{array}$ & 290 & -0.15 & 50 & 57 \\
\hline Pd-Pt NCs & $\begin{array}{c}1 \mathrm{M} \mathrm{KOH}+ \\
1 \mathrm{M} \mathrm{methanol}\end{array}$ & 3500 & -0.15 & 50 & 58 \\
\hline $\mathrm{Pt}-\mathrm{V}_{2} \mathrm{O}_{5} / \mathrm{C}$ & $\begin{array}{c}1 \mathrm{M} \mathrm{KOH} \mathrm{+} \\
1 \mathrm{M} \text { methanol }\end{array}$ & 667 & 0.13 & 50 & 59 \\
\hline $\begin{array}{l}\text { Pt/graphene- } \\
\text { vanadium } \\
\text { carbonitride }\end{array}$ & $\begin{array}{c}1 \mathrm{M} \mathrm{KOH} \mathrm{+} \\
0.5 \mathrm{M} \text { methanol }\end{array}$ & 891 & -0.23 & 50 & 60 \\
\hline $\mathrm{PtAu} / \mathrm{rGO}$ & $\begin{array}{c}1 \mathrm{M} \mathrm{KOH}+ \\
1 \mathrm{M} \text { methanol }\end{array}$ & 637 & 0.13 & 50 & 61 \\
\hline $\begin{array}{c}\text { Pt-poly } \\
\text { (5-nitroindole) }\end{array}$ & $\begin{array}{c}1 \mathrm{M} \mathrm{KOH}+ \\
1 \mathrm{M} \text { methanol }\end{array}$ & 208 & -0.25 & 50 & 62 \\
\hline
\end{tabular}



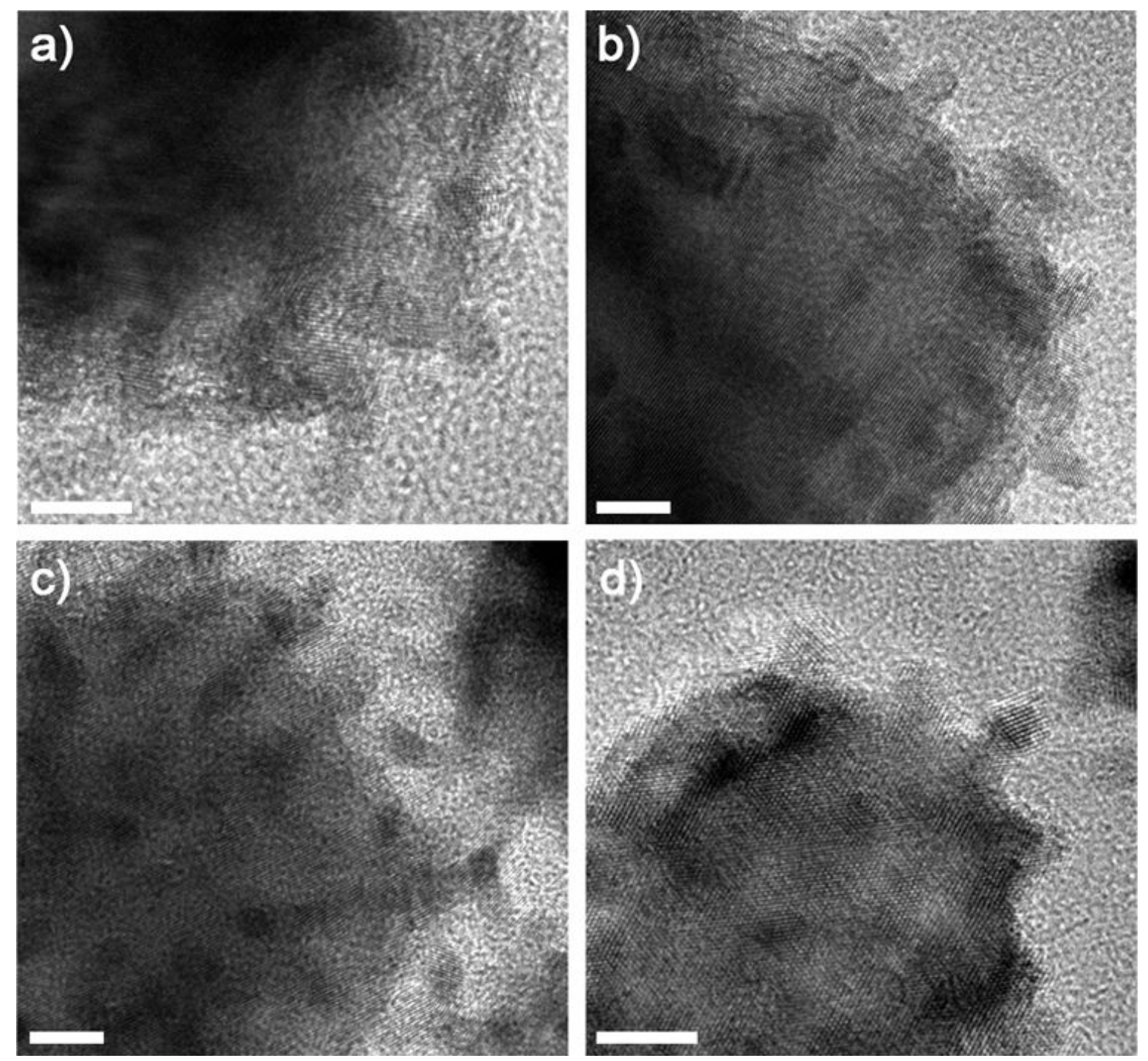

Figure S1. HRTEM images of (a) Au@PdPt, (b) Au@Pd@Pt, (c) AuPd@Pt, and (d) AuPdPt@Pt NCs. Scale bars indicate 5 nm. 

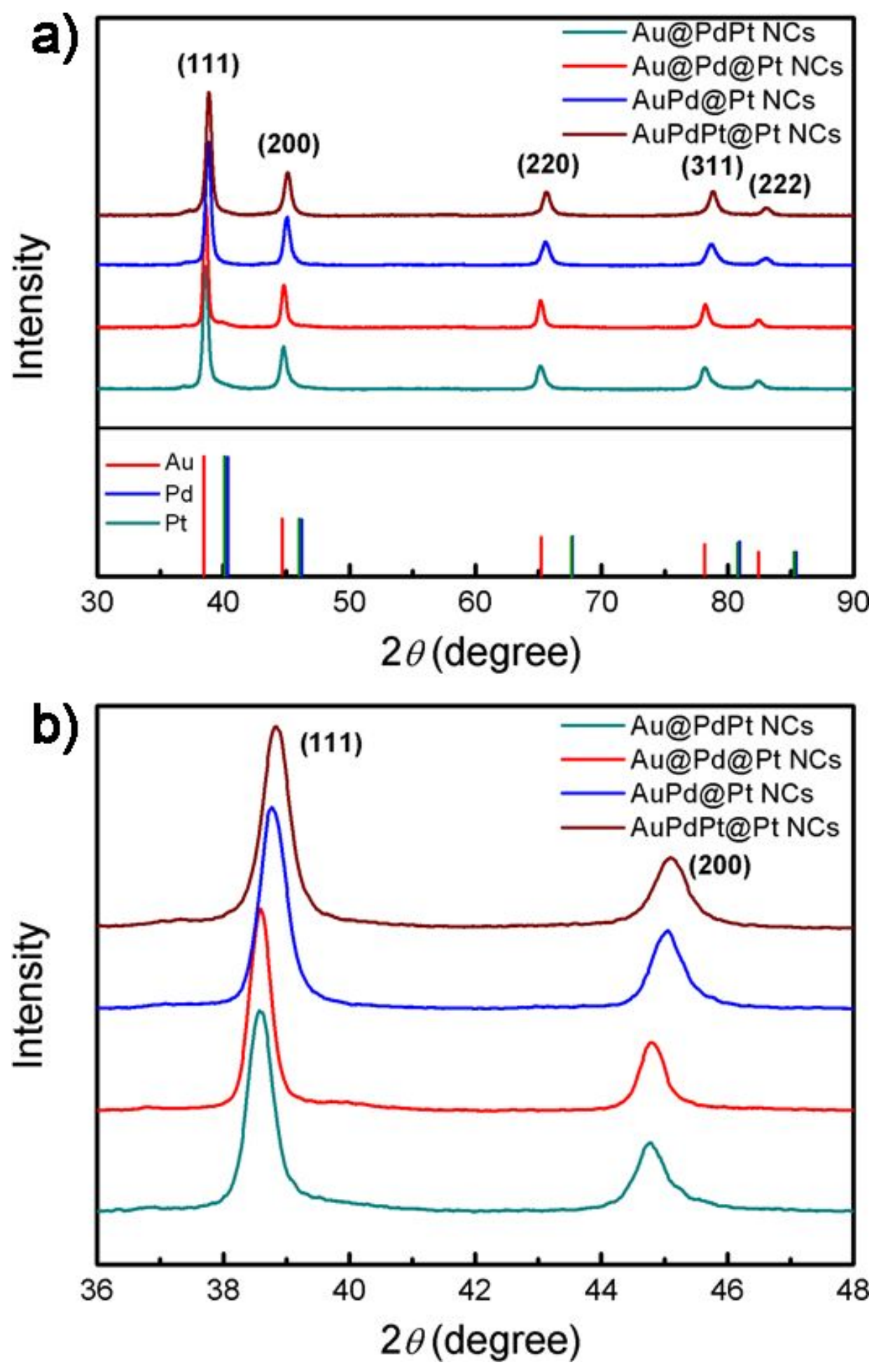

Figure S2. (a)XRD patterns of Au@PdPt, Au@Pd@Pt, AuPd@Pt, and AuPdPt@Pt NCs. The intensities and positions of pure $\mathrm{Au}, \mathrm{Pd}$, and Pt were taken from the JCPDS database. (b) Magnified XRD patterns of NCs. 

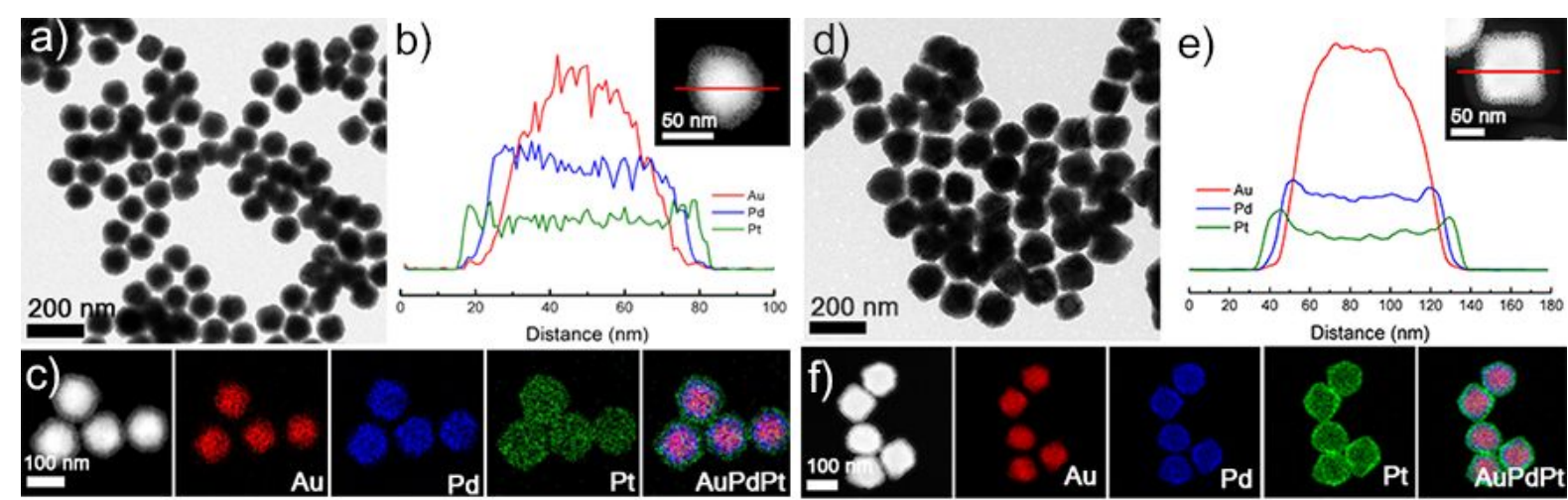

Distance $(\mathrm{nm})$

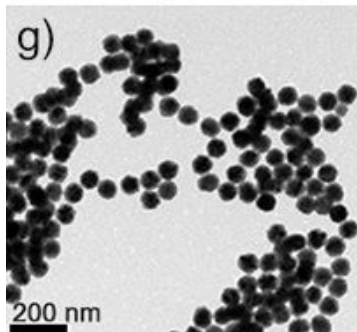

h)
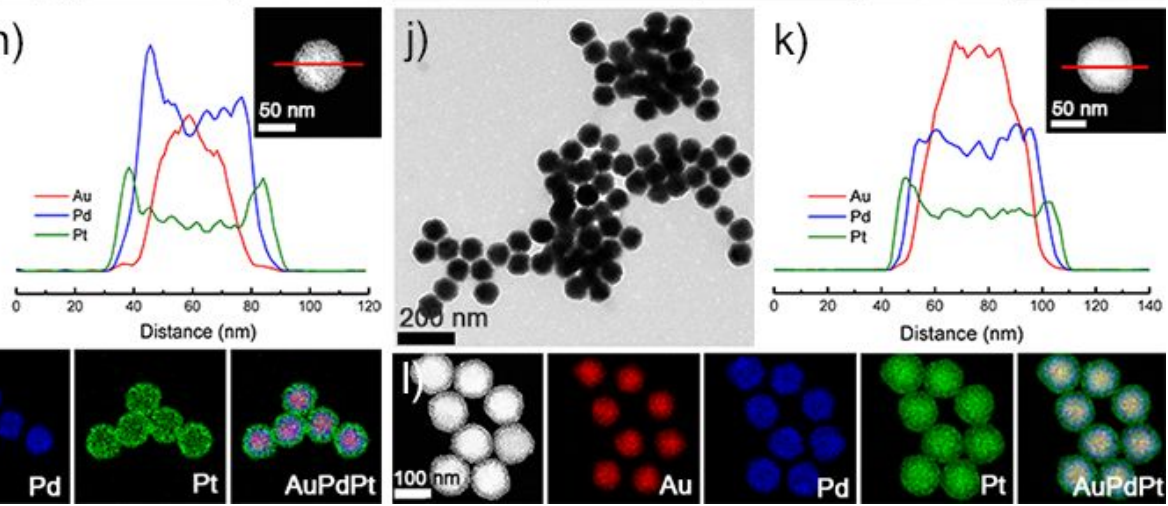

Figure S3. (a,d,g,j) TEM image, (b,e,h,k) HAADF-STEM image and corresponding EDS cross-sectional compositional line profiles of a NC, and (c,f,i,l) HAADF-STEM image and corresponding EDS elemental mapping images of Au@Pd@Pt NCs prepared with $\mathrm{HAuCl} l_{4} / \mathrm{K}_{2} \mathrm{PdCl}_{4} / \mathrm{Na}_{2} \mathrm{PtCl}_{6}$ mixtures in molar ratios of (a-c) 1:1:1, (d-f) 2:1:1, (g-i) 1:2:1, and (j-1) $1: 1: 2$. 

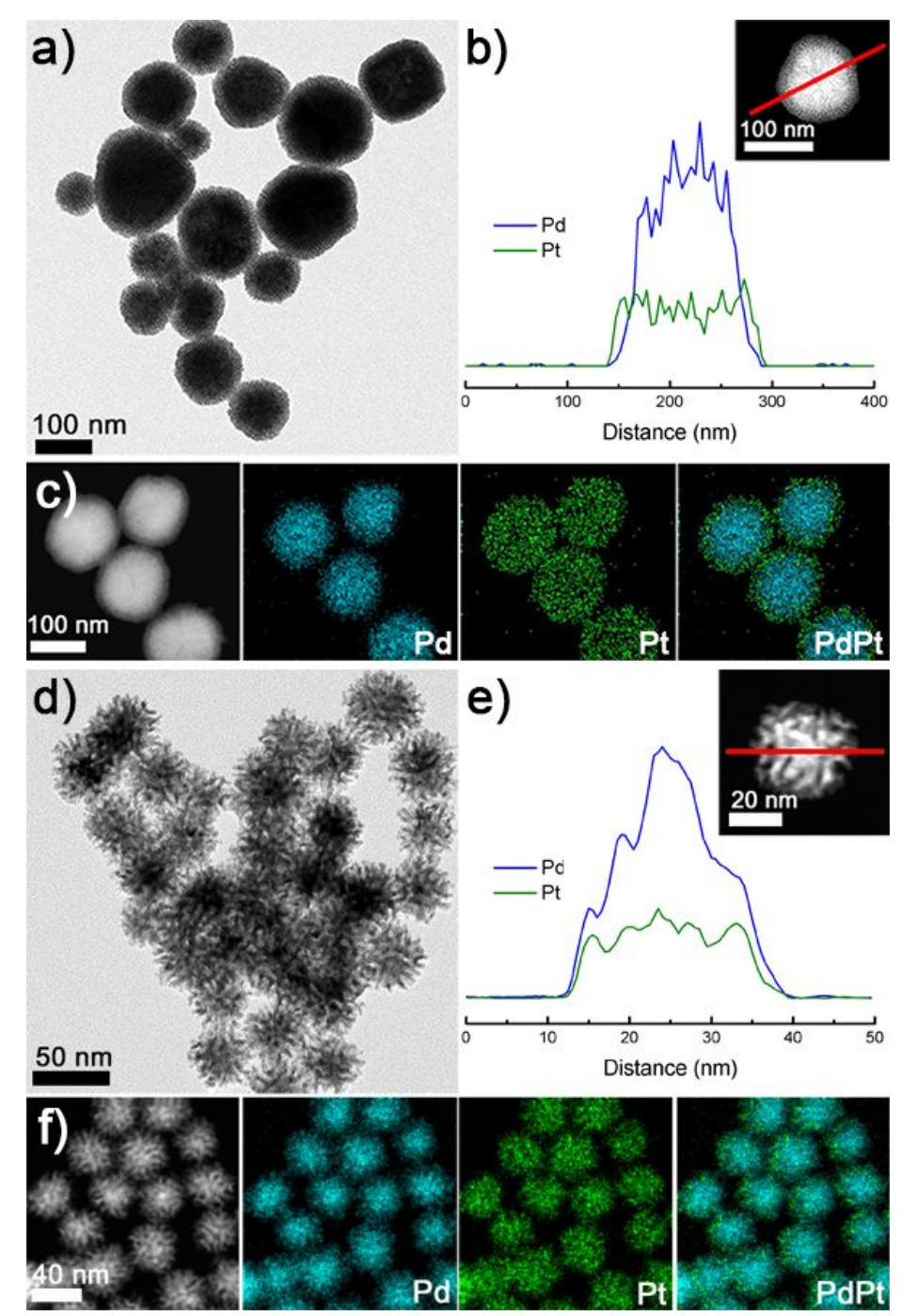

Figure S4. (a,d) TEM image, (b,e) HAADF-STEM image and corresponding EDS crosssectional compositional line profiles of a NC, and (c,f) HAADF-STEM image and corresponding EDS elemental mapping images for NCs prepared in the absence of $\mathrm{Au}$ precursors with (a-c) 10 and (d-f) $50 \mu \mathrm{L}$ of hydrazine solution. 

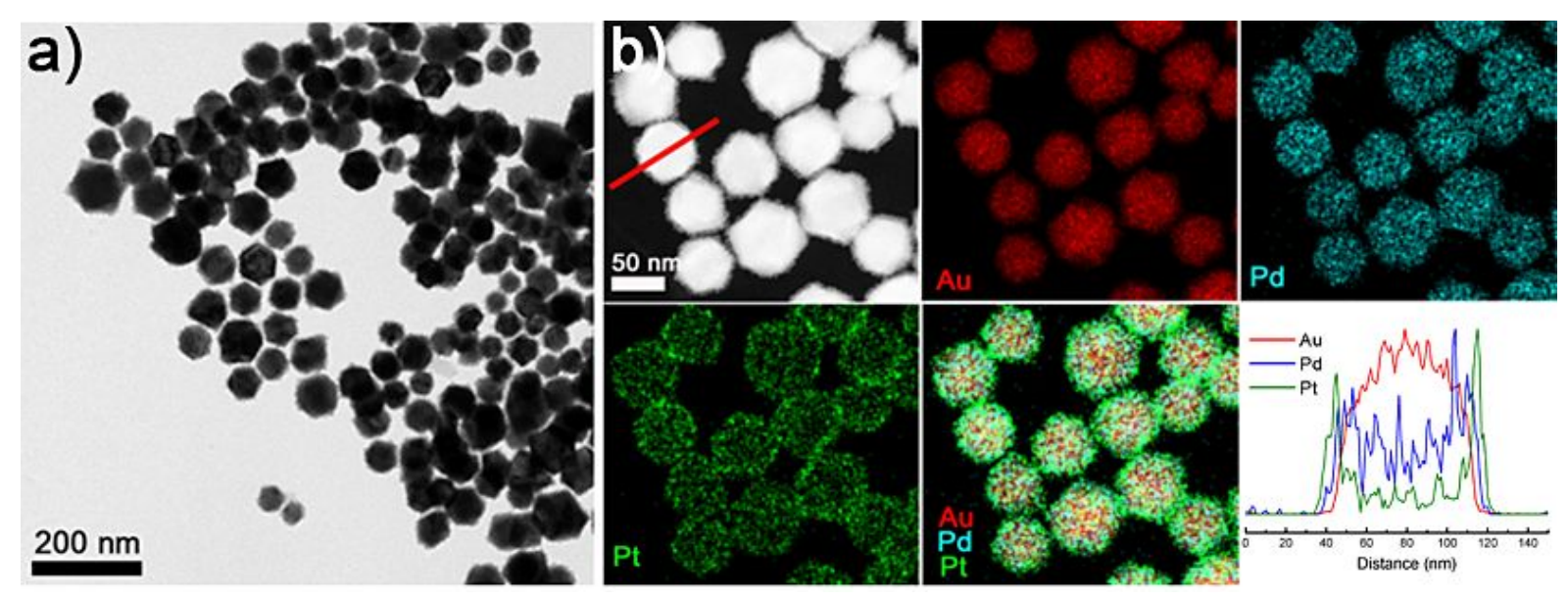

Figure S5. (a) TEM and (b) HAADF-STEM image and corresponding EDS elemental mapping images and cross-sectional compositional line profiles of $\mathrm{Au} @ \mathrm{Pd} @ \mathrm{Pt}$ NCs prepared by using $400 \mu \mathrm{L}$ of $100 \mathrm{mM}$ AA solution. 


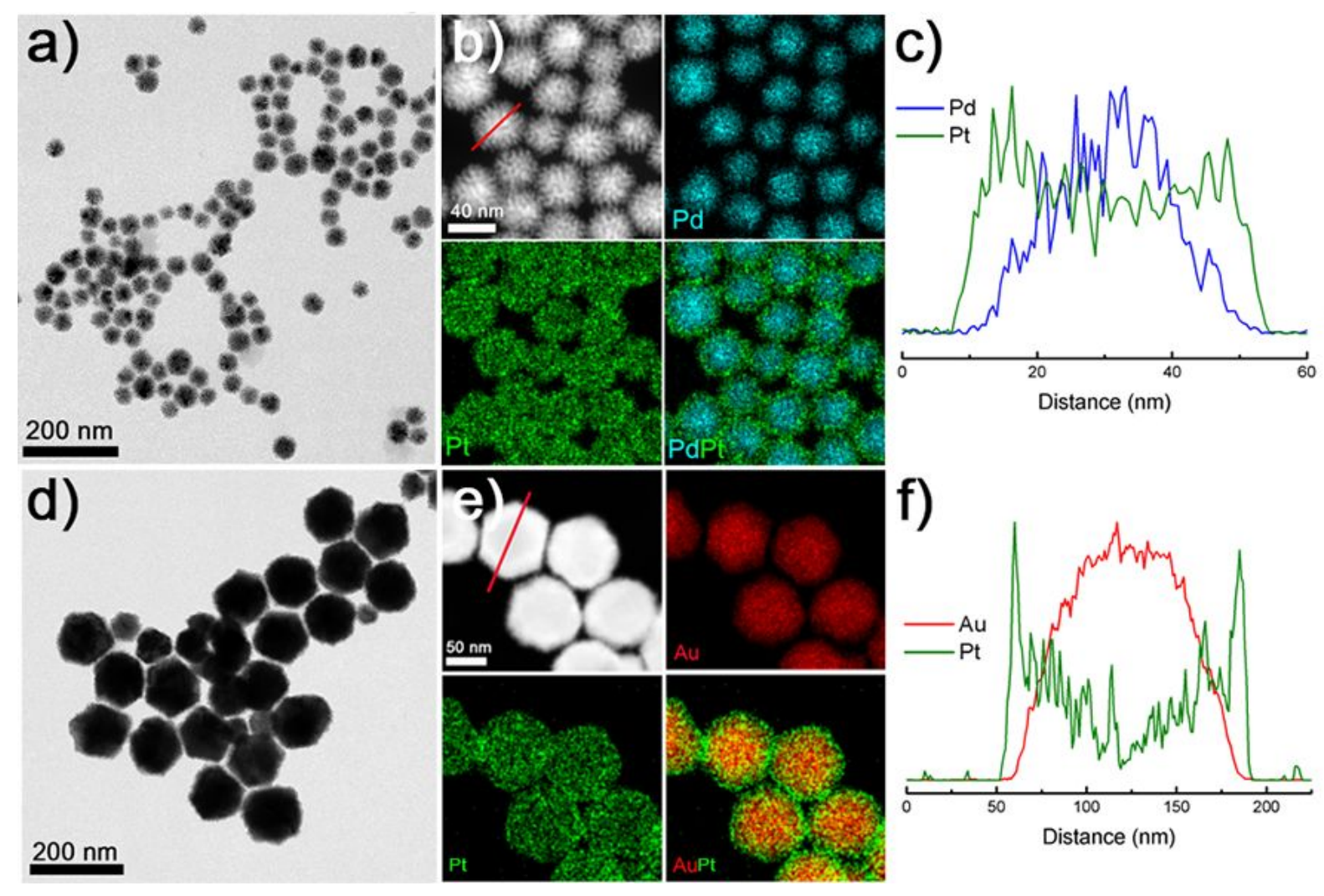

Figure S6. (a,d) TEM image, (b,e) HAADF-STEM image and corresponding EDS elemental mapping images, and (c,f) EDS compositional line profiles of a NC shown in b and e for (a-c) Pd@Pt and (d-f) Au@Pt core-shell NCs. The ICP-MS-determined Pd/Pt and Au/Pt atomic ratios of the Pd@Pt and Au@Pt NCs were 61:39 and 87:13, respectively. 

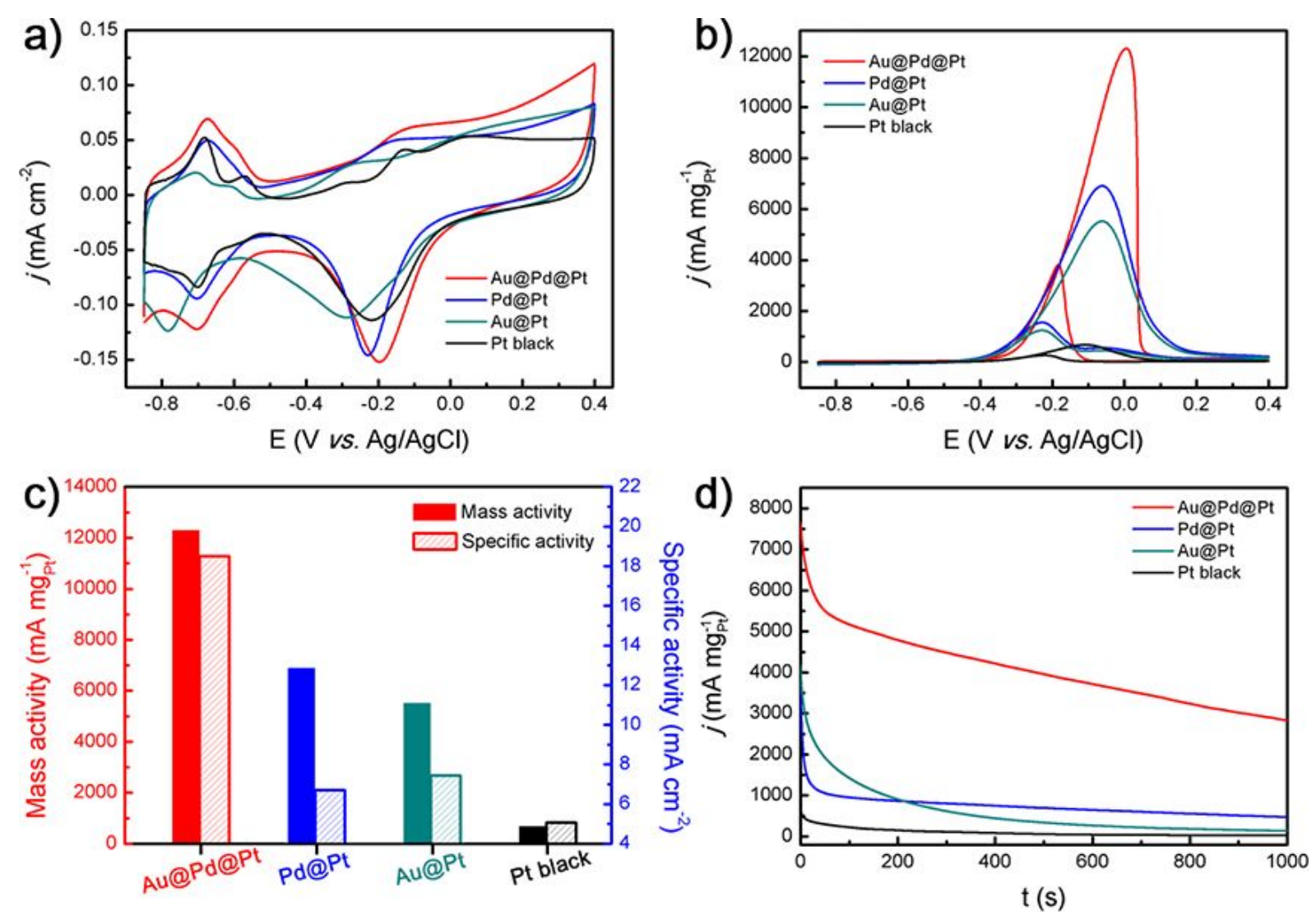

Figure S7.CVs obtained with Au@Pd@Pt NCs, Pd@Pt NCs, Au@Pt NCs, and Pt black in (a) $0.1 \mathrm{M} \mathrm{KOH}$ and (b) $0.1 \mathrm{M} \mathrm{KOH}+0.5 \mathrm{M}$ methanol. Scan rate $=50 \mathrm{mV} \mathrm{s}^{-1}$. The current values in $\mathrm{a}$ and $\mathrm{b}$ were normalized with respect to the ECSA and Pt mass of each catalyst, respectively. (c) Comparison of MOR mass and specific activities between the different catalysts. (d) CA curves of the different catalysts in $0.1 \mathrm{M} \mathrm{KOH}+0.5 \mathrm{M}$ methanol at $-0.1 \mathrm{~V} v s$. $\mathrm{Ag} / \mathrm{AgCl}$. 


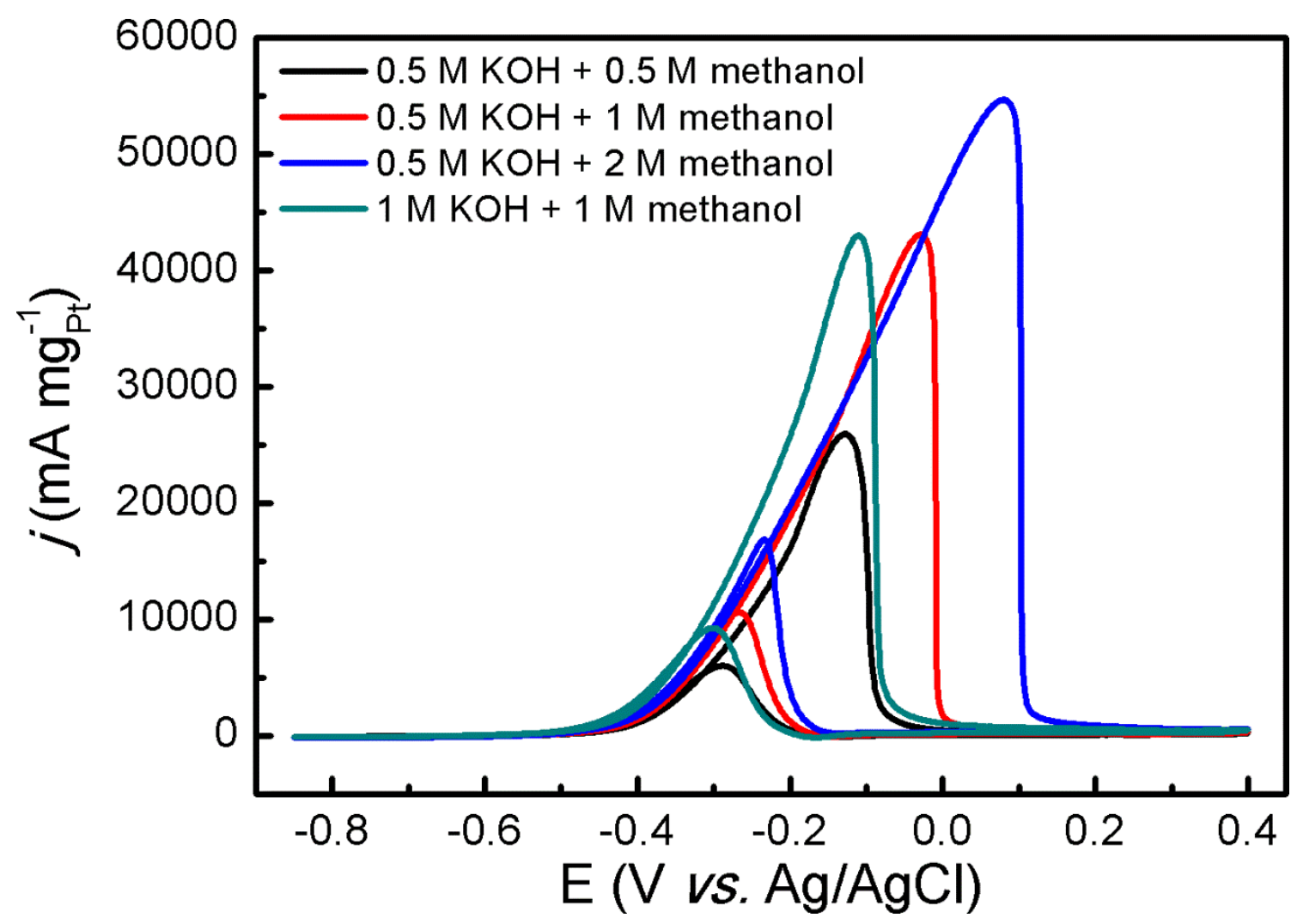

Figure S8. CVs obtained with Au@Pd@Pt NCs under various electrolyte conditions. Scan rate $=50 \mathrm{mV} \mathrm{s}^{-1}$. 

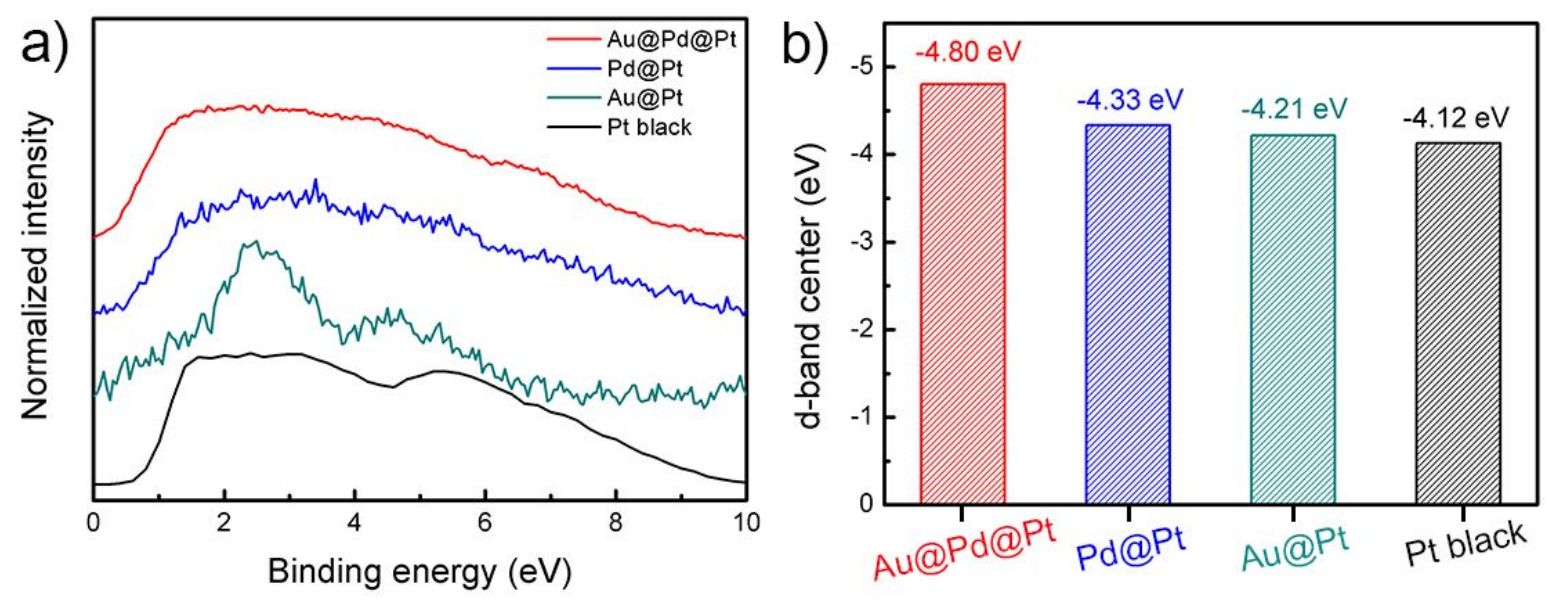

Figure S9. (a) Valence band XPS spectra and (b) d-band center positions relative to the Fermi level of Au@Pd@Pt NCs,Pd@Pt NCs,Au@Pt NCs, and Pt black. 

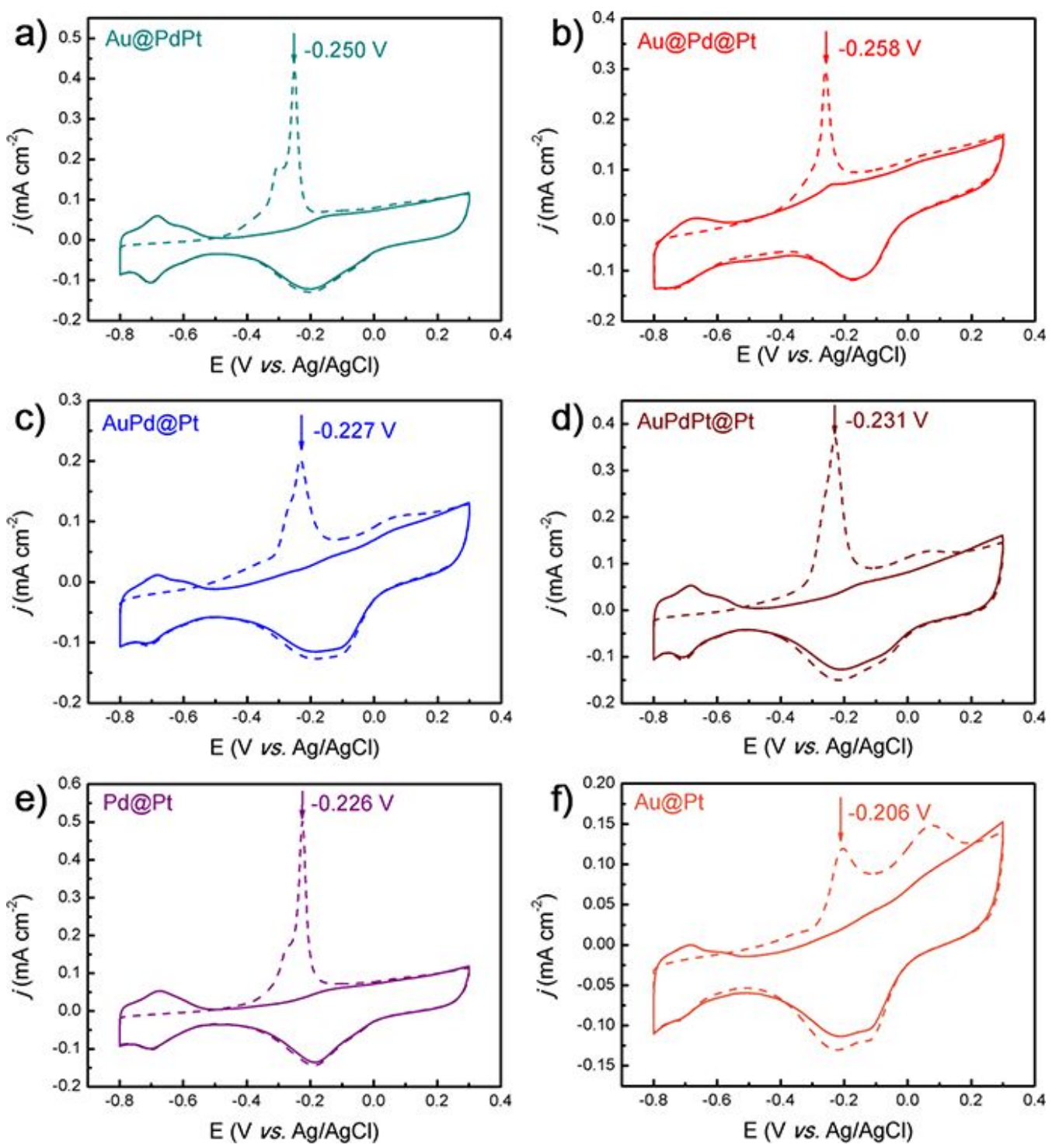

Figure S10. CO stripping voltammograms for (a) Au@PdPt, (b) Au@Pd@Pt, (c) AuPd@Pt, (d) AuPdPt@Pt, (e) Pd@Pt, and (f) Au@Pt NCs in $0.1 \mathrm{M} \mathrm{KOH}$ at a scan rate of $20 \mathrm{mV} \mathrm{s}{ }^{-1}$. The first and second scans are depicted as dashed and solid lines, respectively. 

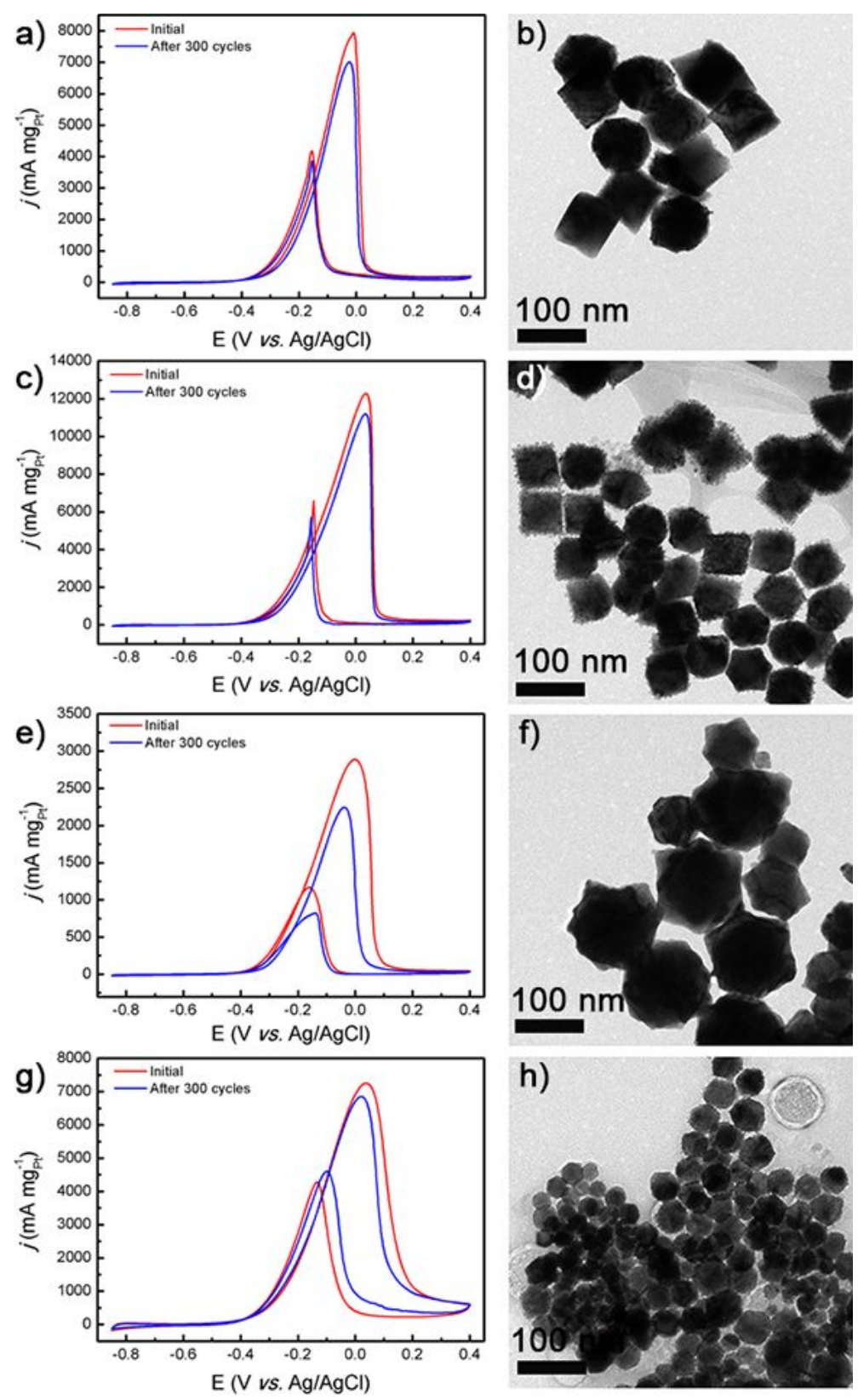

Figure S11. (a,c,e,g) CVs obtained before and after 300 MOR cycles and (b,d,f,h) TEM images after the ADT for (a,b) Au@PdPt, (c,d)Au@Pd@Pt, (e,f) AuPd@Pt, and (g,h) AuPdPt@Pt NCs. 